\title{
Appreciation on Theme Music of Schindler's List
}

\author{
Hongsi Yang ${ }^{1}$ \\ Zhengzhou Railway Vocational \& Technical College, Zhengzhou 450000, China \\ tuke126@126.com
}

Keywords: Schindler's List theme music; frames; humanism film theme.

\begin{abstract}
Schindler's List which is called the colossal one in movie history is directed by Steven Spielberg for as much as ten years old and then generated to be seen and has gain 7 Oscars. The music in the film gimmicky and excellent interpretation of the application of force for film added strong expressive force, make the audience remember its breathtaking behind the melody and rhythm that bloody tragedy of human nature. This article appreciate and analyzes the theme music of the film and make a further study for the theme of the film.
\end{abstract}

\section{Introduction}

Schindler's List is adopted from Thomas Keneally Schindler's 1982 novel of the same name by Steven Spielberg for as much as ten years striving to generate and then released at 1993. To build a documentary general heavy atmosphere, Steven Spielberg take with a hand-held camera mainly with the white and black background revealing the miserable destiny of Jewish family. The composer of this film is famous for Strategic defense initiative, however the excellent work in Schindler's List make he become the real Hollywood master artists. Not only the melody of the theme music is beautiful, but does the twist of the wrist and outstanding interpretation power add more expressive power to the film.

\section{Relationship between theme music and frames}

It is an deceive role that the music play in the film arts. It can be divided the following five situations: picture and music moving simultaneously, running in the equal rank, going to the opposite, playing in an anti-dromic way and stretching with an free drift structure. It is an significant problem to deal with the relationship among them.

Firstly, picture and music moving simultaneously. It is an universal usage to handle the relationship between picture and music, which refers to play the music according to the frames moving especially matching emotionally and in rhythmic. For example, when the lists of survivor's name appeared, the music becomes lively and guide the audience into an comfortable and joyful mood with a happy melody by the alternate using of the violin and accordion. It is filled with an vibrant atmosphere along with the dynamic music playing by the violin and piano accompaniment when the frames of Schindler hiring a typist flashes. The emotion and rhythmic can be in compliance with each other in this long music melody.

Secondly, picture and music running in the equal rank. It refers to exists independently and has an unique representation, which means music does nothing to explain and add any atmosphere about the figure's emotion. It is only effected by auditory touches to help people gain a further understanding and feeling more about the film through each of the music and picture is independent and without affecting. It is persistently continuing at lest ten minutes when theme music appears, in which has along with a lots of different scene: numerous Jewish family are force to left their home by Schutzstaffel, they are marching with the surveillance, many of them are humiliated while Schindler is talking about business leisurely and caring that how to hit a big jackpot. With so many frames but only one theme music, although, it is simple and slow, presents nothing but one theme: the cruel surfer about Jews and their tragic situation. This music profoundly deduce the ruthless and heartless about history. 
And gain, picture and music going to the opposite. This is an special music and picture relationship, required nether to keep up withe the frame emotion nor to explain and add atmosphere to the frame content itself, but to excavate and discover the inter activities about the figure in order to perform the film theme and make a sense of aesthetic for the audience. For instance, the Schindler couple having diner and chatting in the restaurant, dancing, gossiping before sleeping and say goodbye on the station. The melody of the music begins at violin plying and the whole melody is full of the style of dance music. The melody and the scene relationship tightly and loosely, touchingly and separately.

Fourthly, picture and music going to the opposite. It refers to the music and film showing the contents of the inconsistencies, the formation of strong contrast, bring the audience senses a feeling of not harmonious, but easy to cause heart shock. Such situation appears in the film, The German fascist force the Jews take off their cloths regardless of women and men, young and old to receive the naked examine. Once the poor physique person has been discovered, the only result is to be a single shot. The Jews is shouting, crying and scattering in the square. While a German officer handing an album playing music to the public. It is an sharp contrast that the sweet and beautiful music compares with the terrified frame, which makes a extremely stock to the public.

Fifthly, music and film stretching with an free drift structure. The theme music of a film can put off the time playing, which is not only to enhance the details but on the contrary, to reflect the film connotation by the feature of music itself. Therefore the audience can comprehend the theme of the film by their subject feelings with music and film stretching with an free drift structure. Such as, the following situation takes up in the Schindler's List: Schindler stands on the half of a hill seeing the scenes that the Jews are brutally murdered by the German fascist military officers in the city at that time a pure and sweet children sound appears. It seems nothing to do with the cruel murdered scene, but the audience can feel the cruelty of the war from the pure music and make a further understanding about the inter meaning about the film.

\section{Multiple deductive of the theme music}

The theme music that is using Horn Solon as an opening first time to be used in the frame is the Jews are dislodged to leave their home and the music is simple and straight revealing a miserable and deserted feeling as if to open the prelude suffering of the Jews and instruct the audience slowly to the bitterly history age.

The first usage is greatly defer from the style of dance music, which shows the different characters of Jews and Schindler. And there is no double that this music represents the group of Jews.

And latter, the theme music does not stop abruptly but is played for many times.It is a strong power to push the development of the film and make the audience get a further understanding about the relationship of the characters, constantly stimulate the auditory organ of the audience and then in some degree, drive the affect power of the audience to Schindler and the Jews, once the it appears. The method of the music handling is also special at the end of the film. The war has pasted, but it seems like a nightmare stored in the river of history. The Schindler's Jews gain the freedom, and all of them come to the tomb to worship the former rescuer--Schindler. Just at this time the frame becomes color marched the warble of melody, implying the complex affection above word explaining from the groom sound of the piano. Famous violin player Parmin wants to presents the cherish memory of the Jews to Schindler. There is not any words to declare but only the music to cray, to tell what happening in the past while the sad music and piano sound bring people to the bitter ages. This kinds of music is rare but it is the charm point that exists.

\section{Affection humanism reflection of theme music}

The music in Schindler's List plays an important role not only in coordinating the plot and frame but more significant in adding affect atmosphere and performing humanism mood. It is continuing at lest ten minutes when theme music appears, in which has along with a lots of different scene: 
numerous Jewish family are force to left their home by Schutzstaffel, they are marching with the surveillance, many of them are humiliated while Schindler is talking about business leisurely. It is simple and slow, presents nothing but the the feeling of cruel and torment.

The exists of Ammon in the film represents the violent power and he kills people with his own sweet will doing nothing to cherish life let alone to realize the praiseworthy and equality about life.it is the villain sets off the taller, kindness and selfless of Schindler. The talking about Ammon and Schindler after drinking reveals, between liner, the envy of the self control power possessing by Schindler. When Schindler tells him the great power of the word absolve, he tries to imitate but it is the cruel nature make him hard to continue and then he shot the little boy, which can be seen his evil face.

The film has been adopted by two independent scene which makes the two people in the extremely different frames in the situation of trading Jews. Results shows that no matter how hard Ammen tries to imitate Schindler, he never becomes Schindler who kisses the Jews from his heart-feeling while Ammon can never understand how to touch the perfect kindness. Schindler has been dubbed the kiss mice supposed was caught in the jail, Schindler is laugh a lot, while Ammon is accused of scenarios.

The famous violin Parmin is the greatly right person to display such a film background music all by himself. It is certainly to inspire sympathy in the viewers as he perform it with his personal affection. In addition, the cover of the album is a strong hand clutching a small red sleeve stretched out hands, big hands holding hands picture clearly explains the theme of the movie. Red sleeve representing the life and hope, the list of blood typing, Schindler's list, a stabbing pain in everyone's heart, colorful contrast making us more appreciate of peace, disgust and hate war, and all of them push a result that the entire movie theme is so be vividly expressed out.

\section{Conclusion}

All in all, Schindler's list is one of a classic, heart-touched and successful film. For 7 Oscars is not wave to get hollow reputation, it is uncommon to combined the music and frame so subtly and even more rarely to get such laurels especially for black and white film. The charm of the movie theme music is everywhere, such as giving the audience a deep impression, promoting the audience faces the Nazi brutality of hate and misery of sympathy for the Jews and strengthening the sense of reality, history and humanistic feelings. The movie, Schindler's list, will be as time goes on, people gradually forget it classic plot, but the theme music melody will always remain in people's mind, forever.

\section{Reference}

[1] Huang Jia. The exploration of films-an analysis case as Schindler's list. Film Literature. Vol. 4 (2008).

[2] WenHao Zheng. Discussion of film music from the background music of Schindler's list. National Music. Vol. 4 (2008).

[3] AoYuan Jin Discuss about the expression function of film music to character affection. Music Maxvision. Vol. 6 (2011).

[4] Chunliu Wang. The application of music in film. News Transmission. Vol. 5 (2011).

[5] QianWu, LinLi. The idea about the two problems in the background music of Schindler's list. Film Assessment. Vol. 5 (2008). 